\title{
TU/e emonownen

\section{'Dip'-formation in phase-sensitive ac-voltammetry as a result of the uncompensated resistance}

\section{Citation for published version (APA):}

Schreurs, J. P. G. M., \& Barendrecht, E. (1984). 'Dip'-formation in phase-sensitive ac-voltammetry as a result of the uncompensated resistance. Journal of Electroanalytical Chemistry and Interfacial Electrochemistry, 175(1-2), 313-316. https://doi.org/10.1016/S0022-0728(84)80365-4

DOI:

10.1016/S0022-0728(84)80365-4

Document status and date:

Published: 01/01/1984

\section{Document Version:}

Publisher's PDF, also known as Version of Record (includes final page, issue and volume numbers)

\section{Please check the document version of this publication:}

- A submitted manuscript is the version of the article upon submission and before peer-review. There can be important differences between the submitted version and the official published version of record. People interested in the research are advised to contact the author for the final version of the publication, or visit the $\mathrm{DOI}$ to the publisher's website.

- The final author version and the galley proof are versions of the publication after peer review.

- The final published version features the final layout of the paper including the volume, issue and page numbers.

Link to publication

\section{General rights}

Copyright and moral rights for the publications made accessible in the public portal are retained by the authors and/or other copyright owners and it is a condition of accessing publications that users recognise and abide by the legal requirements associated with these rights.

- Users may download and print one copy of any publication from the public portal for the purpose of private study or research.

- You may not further distribute the material or use it for any profit-making activity or commercial gain

- You may freely distribute the URL identifying the publication in the public portal.

If the publication is distributed under the terms of Article 25fa of the Dutch Copyright Act, indicated by the "Taverne" license above, please follow below link for the End User Agreement:

www.tue.nl/taverne

Take down policy

If you believe that this document breaches copyright please contact us at:

openaccess@tue.nl

providing details and we will investigate your claim. 
Elsevier Sequoia S.A., Lausanne - Printed in The Netherlands

\section{Short communication}

\section{“DIP”-FORMATION IN PHASE-SENSITIVE AC-VOLTAMMETRY AS A RESULT OF THE UNCOMPENSATED RESISTANCE}

\section{J. SCHREURS and E. BARENDRECHT}

Laboratory of Electrochemistry, Department of Chemical Engineering, Eindhoven University of Technology, P.O. Box 513, 5600 MB Eindhoven (The Netherlands)

(Received 14th February 1984; in revised form 30th March 1984)

During research [1] on surface modified electrodes (SME), we encountered a remarkable phenomenon in the phase-sensitive $\left(\lambda=90^{\circ}\right)$ ac-voltammograms of a cobalt-tetra $\left(p\right.$-aminophenyl)porphyrin $\left(\mathrm{CoT}\left(\mathrm{pNH}_{2}\right) \mathrm{PP}\right)$ modified glassy carbon $(\mathrm{Cg})$ electrode. Upon increasing the frequency, a dip arises in the redox peak, exactly at its peak potential (Fig. 1a). Further increase of the frequency turns the peak upside down and then forces an increase in this direction. Finally, this peak decreases again $(f>150 \mathrm{~Hz})$ and only the double-layer charging current is observed. This unexpected behaviour could not be explained at first, but simulation of the ac-voltammogram made it clear that this effect is due to the uncompensated (electrolyte) resistance $\left(R_{\mathrm{u}}\right)$. For this simulation, the equivalent circuit shown in Fig. 2 was used. The current $(i)$ for the phase-sensitive ac-voltammogram, at a detection angle $(\lambda)$ of $90^{\circ}$, is expressed by

$i\left(\lambda=90^{\circ}\right)=\epsilon Y^{\prime \prime} \cos \omega t=\epsilon \frac{Z^{\prime \prime}}{\left(Z^{\prime}\right)^{2}+\left(Z^{\prime \prime}\right)^{2}} \cos \omega t$

where $\epsilon$ is the modulation amplitude, $\omega$ the angular frequency, and $Y^{\prime \prime}$ the imaginary part of the admittance, which is composed of the real $\left(Z^{\prime}\right)$ and the imaginary $\left(Z^{\prime \prime}\right)$ part of the impedance. For the equivalent circuit used, $Z^{\prime}$ and $Z^{\prime \prime}$ are given by

$Z^{\prime}=R_{\mathrm{u}}+\frac{R_{\mathrm{f}} C_{\mathrm{f}}^{2}}{\left(C_{\mathrm{f}}+C_{\mathrm{d}}\right)^{2}+\left(\omega R_{\mathrm{f}} C_{\mathrm{f}} C_{\mathrm{d}}\right)^{2}}$

$Z^{\prime \prime}=\frac{C_{\mathrm{d}}+C_{\mathrm{f}}+\left(\omega R_{\mathrm{f}} C_{\mathrm{f}}\right)^{2} C_{\mathrm{d}}}{\omega\left[\left(C_{\mathrm{f}}+C_{\mathrm{d}}\right)^{2}+\left(\omega R_{\mathrm{f}} C_{\mathrm{f}} C_{\mathrm{d}}\right)^{2}\right]}$

where $C_{\mathrm{d}}$ is the double-layer capacity and $R_{\mathrm{u}}$ the uncompensated solution resistance, which can be calculated from [2]:

$R_{\mathrm{u}}=(2 \kappa d)^{-1}$

for a disc electrode (diameter $d$ ) in the case of a primary current distribution ( $\kappa$ 
being the specific conductivity). The faradaic resistance $\left(R_{\mathrm{f}}\right)$ and capacity $\left(C_{\mathrm{f}}\right)$, however, depend on the electrode potential as expressed by [3] (quasi-reversible charge transfer):

$R_{\mathrm{f}}=\frac{R T}{n^{2} F^{2} A \Gamma_{\mathrm{T}} k_{\mathrm{s}}}\left(\xi^{\alpha}+\xi^{\alpha-1}\right)$

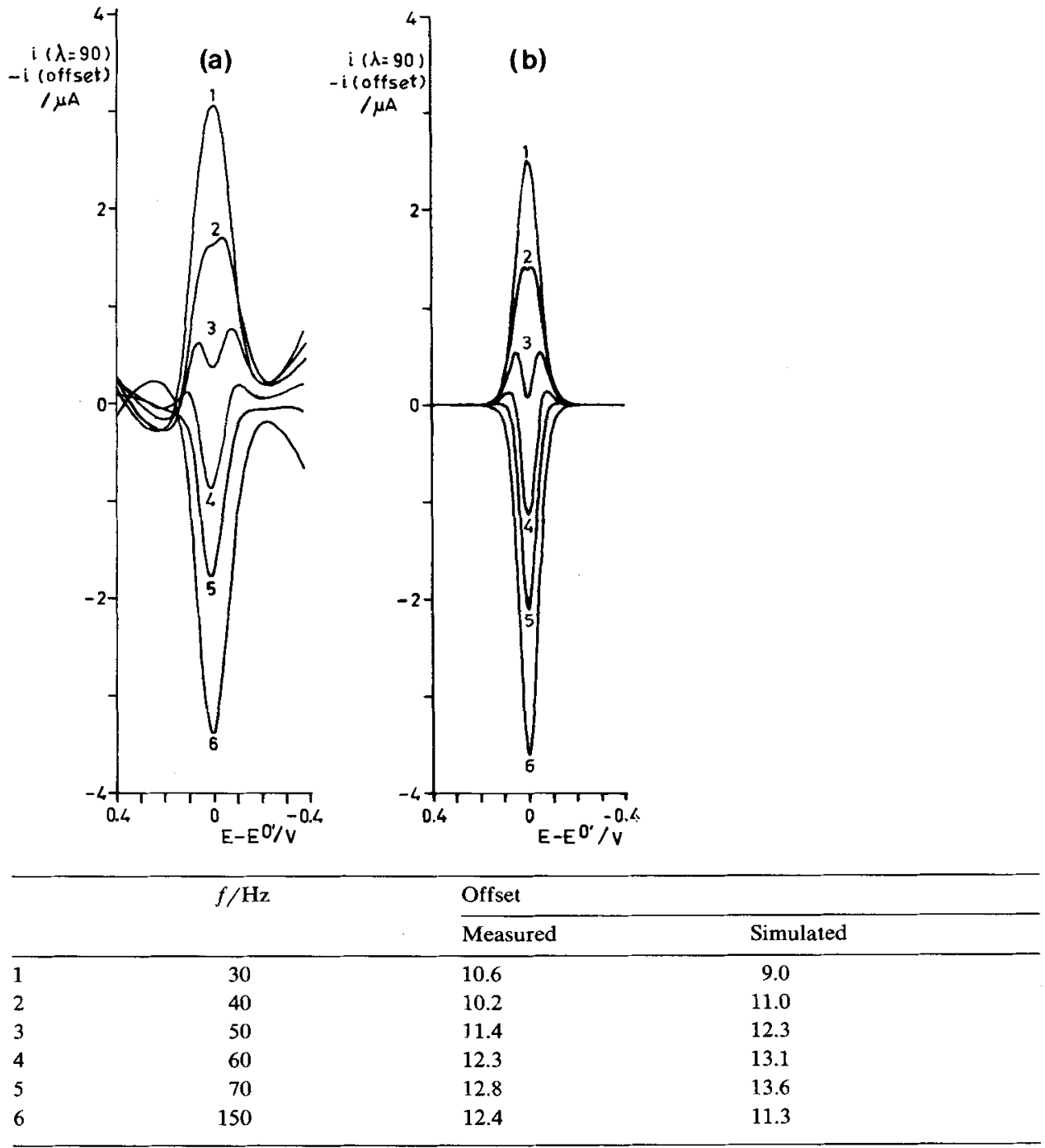

Fig. 1. Phase-selective ac-voltammograms of a $\mathrm{Co}(\mathrm{II}) \mathrm{T}\left(\mathrm{pNH}_{2}\right) \mathrm{PP}$ modified Cg-electrode. (a) Measured for different frequencies in 0.1 M TEAP/DMSO $\left(\kappa=2.4410^{-3} \Omega^{-1} \mathrm{~cm}^{-1}\right), \lambda=90^{\circ}, \epsilon=0.01 \mathrm{~V}(\mathrm{rms})$, $v=0.02 \mathrm{~V} \mathrm{~s}^{-1}$. (b) Simulated with $\lambda=90^{\circ}, \epsilon=0.01 \mathrm{~V}, R_{\mathrm{u}}=90 \Omega \mathrm{cm}^{2}, C_{\mathrm{d}}=22.2 \mu \mathrm{F} \mathrm{cm} \mathrm{cm}^{-2}, \Gamma_{\mathrm{T}}=1.5 \times$ $10^{-11} \mathrm{~mol} \mathrm{~cm}{ }^{-2}, A=0.246 \mathrm{~cm}^{2}$, and $k_{\mathrm{s}}=590 \mathrm{~s}^{-1}\left(C_{\mathrm{f}}=14.1 \mu \mathrm{F} \mathrm{cm} \mathrm{cm}^{-2}\right.$ and $R_{\mathrm{f}}=60 \Omega \mathrm{cm}^{2}$ at $\left.E=E^{\circ \prime}\right)$. 

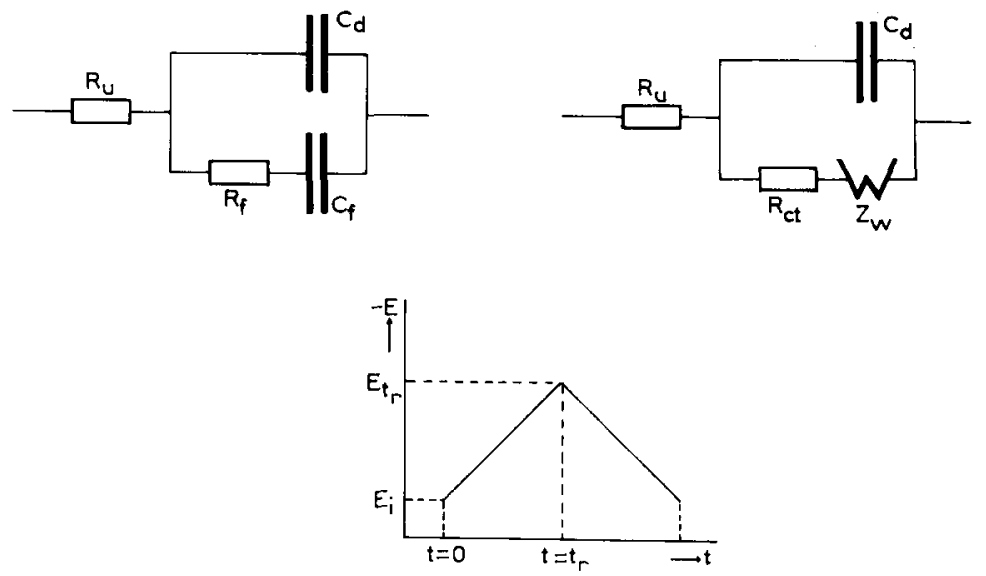

Fig. 2. Equivalent circuit for surface modified electrode; both $O$ and $R$ attached to the surface. $R_{u}$, Uncompensated resistance; $C_{\mathrm{d}}$, double-layer capacity; $R_{\mathrm{f}}$, faradaic resistance; $C_{\mathrm{f}}$, faradaic capacity; $R_{\mathrm{ct}}$, charge tranfer resistance; $Z_{w}$, Warburg impedance.

and

$C_{\mathrm{f}}=\frac{n^{2} F^{2} A \Gamma_{\mathrm{T}}}{R T} \frac{\xi}{(1+\xi)^{2}}$

where

$\xi=\exp (n F / R T)\left(E-E^{\circ \prime}\right)$

The symbols $\alpha, n, F, R, T$, and $E$ have their usual meaning and $k_{\mathrm{s}}\left(\mathrm{s}^{-1}\right)$ stands for the rate constant of the surface reaction. The double-layer capacity $\left(C_{\mathrm{d}}\right)$ and the total surface concentration $\left(\Gamma_{\mathrm{T}}\right)$ are determined from the ac-voltammogram at 30 Hz. Substitution of eqns. (2)-(6) into eqn. (1) yields a general expression for the ac-voltammogram, at a detection angle $(\lambda)$ of $90^{\circ}$, in which the uncompensated resistance is accounted for. This expression was used for simulation of the measured voltammograms. As can be seen from Fig. 1b, the simulations agree very well with the observed changes in the ac-voltammograms upon increasing the frequency (see Fig. 1a). This remarkable behaviour primarily results from the uncompensated (mainly electrolyte) resistance $\left(R_{\mathrm{u}}\right)$, but is intensified by the faradaic resistance, i.e. reaction rate. No dip-formation occurs when $R_{\mathrm{u}}=0$. For increasing values of $R_{\mathrm{f}}$ $\left(R_{\mathrm{u}} \neq 0\right.$ ), dip-formation occurs at lower frequencies. The best fit of the simulation was obtained for a surface reaction rate constant $\left(k_{\mathrm{s}}\right)$ of $590 \mathrm{~s}^{-1}$. From cyclic voltammetry, a rate constant $k_{\mathrm{s}}=24 \mathrm{~s}^{-1}$ was determined [1]. This value is probably too low since it was calculated from the peak potential difference $\left(\Delta E_{\mathrm{p}}\right)$ which approached $\approx 15 \mathrm{mV}$ and not the expected zero value at low potential scan rates $(v)$. If the graph $\cot \phi=f(\omega)$ is used for the determination of $k_{\mathrm{s}}$, then not only $R_{\mathrm{u}}$ but also $C_{\mathrm{d}}$ must be taken into account because the faradaic phase angle $\left(\phi_{\mathrm{f}}\right)$ and not the measured phase angle $(\phi)$ must be used. 
It should also be noted that peak broadening occurs, which is frequency-dependent. This peak broadening, calculated from the simulation, does not completely explain the one experimentally observed, so non-ideal behaviour, as described by Brown and Anson [4] and Murray and co-workers [5], must still be taken into account. The appearance of a dip in the peak of the ac-voltammogram results, for a certain frequency region, in apparently two peaks, which can be very confusing for interpretation.

A similar phenomenon can be observed if redox species in solution are detected by ac-voltammetry at a detection angle of $90^{\circ}$ instead of $45^{\circ}$. Phase-sensitive ac-voltammetry should therefore be performed at different frequencies and in combination with cyclic voltammetry to avoid erroneous interpretations.

\section{REFERENCES}

1 J. Schreurs, Thesis, University of Technology, Eindhoven, 1983.

2 J.S. Newman, in Electrochemical Systems, Prentice-Hall, Englewood Cliffs, 1973, p. 344.

3 E. Laviron, J. Electroanal. Chem., 97 (1979) 135.

4 A.P. Brown and F.C. Anson, Anal. Chem., 49 (1977) 1589.

5 D.F. Smith, K. Willman, K. Kuo and R.W. Murray, J. Electroanal. Chem., 95 (1979) 217. 